Comparison of Dark Adaptation with the Psychological STATE IN MINERS

\title{
A COMPARISON OF DARK ADAPTATION WITH THE PSYCHOLOGICAL STATE IN MINERS
}

BY

\section{DoRothy ADAMS CAMPBELL}

\author{
COVENTRY
}

Livingston and Bolton (1943) showed that the night visual capacity of different individuals might be due to varying attitudes of mind. Among 50 psychological in-patients of the R.A.F. those with an anxiety state were found to be incapable of concentration and to have a poor night visual capacity. Hysterics failed

TABLE I.-Comparison with psychological state (65 cases).

\begin{tabular}{|c|c|c|c|c|c|c|c|}
\hline & Normal & $\begin{array}{l}\text { Malin- } \\
\text { gerer }\end{array}$ & Hysteria & $\begin{array}{l}\text { Anxiety } \\
\text { Neurosis }\end{array}$ & $\begin{array}{l}\text { Obsess. } \\
\text { Neurosis }\end{array}$ & $\begin{array}{l}\text { Dull and } \\
\text { Backward }\end{array}$ & $\begin{array}{l}\text { Manic-De- } \\
\text { pressive }\end{array}$ \\
\hline $\begin{array}{c}\text { Early symptoms : } \\
\text { no nystagmus }\end{array}$ & & - & $2 \cdot 49$ & - & 1.83 & & $2 \cdot 11$ \\
\hline $\begin{array}{c}\text { Control miners } \\
\text { with no } \\
\text { nystagmus }\end{array}$ & $\begin{array}{l}3 \cdot 01 \\
2 \cdot 85 \\
1.83 \\
1 \cdot 77 \\
2 \cdot 67 \\
2 \cdot 31 \\
1.85\end{array}$ & $\begin{array}{l}- \\
- \\
- \\
- \\
-\end{array}$ & $\begin{array}{l}- \\
- \\
- \\
- \\
-\end{array}$ & $\begin{array}{c}2 \cdot 85 \\
2 \cdot 01 \\
2 \cdot 59 \\
2 \cdot 01 \\
3 \cdot 17 \\
- \\
-\end{array}$ & $\begin{array}{c}2 \cdot 57 \\
- \\
- \\
- \\
-\end{array}$ & $\begin{array}{c}2 \cdot 37 \\
2 \cdot 67 \\
- \\
= \\
= \\
-\end{array}$ & $\begin{array}{l}2 \cdot 89 \\
2 \cdot 17 \\
1 \cdot 95 \\
2 \cdot 35 \\
2 \cdot 13 \\
2 \cdot 31 \\
1.81\end{array}$ \\
\hline Average & $2 \cdot 61(7)$ & - & - & $2 \cdot 47(5)$ & - & $2 \cdot 57(2)$ & $2 \cdot 27(7)$ \\
\hline $\begin{array}{l}\text { Certified cases } \\
\text { with active } \\
\text { nystagmus }\end{array}$ & $\begin{array}{l}- \\
- \\
- \\
- \\
-\end{array}$ & $\begin{array}{l}- \\
- \\
- \\
-\end{array}$ & $\begin{array}{l}2 \cdot 35 \\
2 \cdot 27 \\
1 \cdot 91 \\
2 \cdot 81 \\
1.97 \\
2 \cdot 07\end{array}$ & $\begin{array}{l}2 \cdot 25 \\
2 \cdot 07 \\
2 \cdot 25 \\
2 \cdot 17 \\
2 \cdot 31 \\
2 \cdot 75\end{array}$ & $\begin{array}{l}- \\
- \\
-\end{array}$ & $\begin{array}{l}\text { N.T. } \\
2.57 \\
- \\
= \\
-\end{array}$ & $\begin{array}{l}2 \cdot 15 \\
- \\
- \\
-\end{array}$ \\
\hline Average & - & - & $2 \cdot 23(6)$ & $2 \cdot 29(6)$ & - & $2 \cdot 57$ & $2 \cdot 15$ \\
\hline $\begin{array}{l}\text { Certified cases } \\
\text { with no } \\
\text { nystagmus }\end{array}$ & $\begin{array}{c}2 \cdot 11 \\
2 \cdot 07 \\
- \\
- \\
- \\
- \\
-\end{array}$ & $\begin{array}{c}2 \cdot 31 \\
- \\
- \\
- \\
- \\
-\end{array}$ & $\begin{array}{l}2 \cdot 59 \\
2 \cdot 93 \\
2 \cdot 13 \\
2 \cdot 37 \\
1 \cdot 71 \\
3 \cdot 1 * \\
2: 47 \\
-.\end{array}$ & $\begin{array}{l}2 \cdot 33 \\
2 \cdot 41 \\
2 \cdot 21 \\
4 \cdot 21 \\
2 \cdot 51 \\
2 \cdot 89 \\
2 \cdot 47 \\
2 \cdot 79\end{array}$ & $\begin{array}{l}- \\
- \\
- \\
- \\
- \\
-\end{array}$ & $\begin{array}{c}2 \cdot 8^{\circ} \\
- \\
- \\
- \\
- \\
-\end{array}$ & $\begin{array}{c}3.16 \\
\text { N.T. } \\
- \\
- \\
- \\
- \\
-\end{array}$ \\
\hline Average & $2 \cdot 09(2)$ & $2 \cdot 31$ & $2 \cdot 36(6)$ & $2 \cdot 54(7)$ & - & - & $3 \cdot 16$ \\
\hline $\begin{array}{l}\text { Active nystagmus } \\
\text { with no symptoms }\end{array}$ & $2 \cdot 65$ & - & - & - & - & $2 \cdot 91$ & $2 \cdot 21$ \\
\hline $\begin{array}{l}\text { Average for all } \\
\text { miners }(65)\end{array}$ & $2 \cdot 30(10)$ & $2 \cdot 31(1)$ & $2 \cdot 30(12)$ & $2 \cdot 35(18)$ & (1) & $2 \cdot 68(4)$ & $2 \cdot 45(10)$ \\
\hline
\end{tabular}

Figures in brackets $=$ number of individual tests.

* Tests done but not accepted as reliäble. 
markedly, whereas depressives even where some anxiety background had been revealed, seemed capable of making a reasonable effort.

Although the tests for dark adaptation do not involve the same mental judgment as night vision tests-it was considered interesting in the case of miners to compare the threshold values obtained by Dr. Sharpley with the psychological tests made by Dr. Stern. The results are recorded in Table 1.

It will be seen that for the total 65 miners tested, the average threshold values in the cases of hysterics, anxiety neurosis and malingerers are the same as for normal mentality, whereas it is higher in manic depressives and in the dull and backward.

In the group of control miners, the psychologically abnormal had a lower threshold than the normal, while in the certified cases the rise in threshold in hysteria and anxiety neurosis was more marked in those without nystagmus than in those with active oscillations.

\section{Conclusion}

The evidence such as it is points to the fact that among miners there is no significant relationship between the psychological state and the threshold of dark adaptation. It would be interesting to compare them with a group of ordinary workmen in this respect.

\section{REFERENCE}

Livingston, P. C. and Bolton, Beryl.-Lancet, p. 263, February 27, 1943.

\section{BINOCULAR VISION IN MINERS}

BY

\section{Dorothy ADAMS CAMPBEll, RENEE HARRISON and JEAN VERTIGEN}

THEsE preliminary investigations were made in the hope that a minute study of the behaviour of the eyes under conditions of low illumination might reveal the mode of onset of nystagmus.

The binocular vision of miners was compared with that of a large group of normal subjects of the same age groups :-

(a) in full light adaptation.

(b) in full dark adaptation (after 45 minutes in the dark).

The tests were made on the synoptophore, using test slides calibrated for known illuminations. For tests (a) the illumination 